\title{
The Increase \\ of Organic Carbon and Total Nitrogen Accumulation under Pine Tree Stands in the Areas Affected by the Exploitation of Sands after Forest Land Reclamation**
}

\section{Introduction}

The assessment of the success of the applied methods of reclamation is a complex issue resulting from a large number of factors deciding both on the growth of the vegetation and the development of soil-forming processes. Also, because of that the results of the studies are limited to selected questions such as the influence of time on the increase of basic bio-elements $(\mathrm{C}, \mathrm{N})$, organic matter, activity of microorganisms etc. depending on the species composition of the tree stand. One should emphasize that these studies refer to the changes taking place in the formations during first periods of the growth of the introduced vegetation. In the obtained so far results, the maximum period referring to the area is seventy years, and usually the period of vegetation growth ranges between 10 and 40 years [4]. The results indicate rapid development of soil microorganisms, with enzyme activity close to mature soils, although the accumulation of the organic matter is slower, both in terms of the small thickness of horizons $(\mathrm{O}, \mathrm{A})$ as well as the amount of accumulated carbon or nitrogen, which proves that reaching the climax stage by such soils, in our climatic conditions would take a long time and so far the process has been remaining unknown $[2,5,7,8]$.

The results presented in this paper document the increase of total carbon and total nitrogen in sand-like formations (loose sands of the colloid clay content not exceeding 2\%) under the influence of one-species forestations (Pinus sylvestris). The value of the increase of the content was calculated only in the organic horizons $\left(\mathrm{O}_{\mathrm{lf}}\right)$ and in initial organic-mineral horizons $\left(\mathrm{A}_{\mathrm{an}} \mathrm{C}_{\mathrm{an}}\right)$ possible in deeper is low, close to the limit of detectability. Similar initial properties of the formations allow the assessment of the influence of one factor such as the duration of growth in this case.

* AGH University of Science and Technology, Faculty of Mining Surveying and Environmental Engineering, Krakow, Poland

** The study has been finance by Polish Ministry of Science and Higher Education from research resources of 20100-2013 as the research Project nr N N523 614539 


\section{The Characteristics of the Study Area}

The studies were carried out on four plots covered with forest grown in the framework of the reclamation measures on post-mining areas of the former Sand Quarry "Szczakowa". Fluvial and glacial formations were deposed in this area 80-240 thousand years ago, however, in the marked fields almost exclusively sands were exploited (for stowing in mines and for the construction industry). As a result of mining works the pits were made 5-20 metres deep, the floor of which is built of the remained sands.

During the reclamation works different methods were applied to increase the fertility of unfavourable formations: fertilizing with an organic substance (humus) and cultivation of herbal plants for two years, ploughing the green mass, as organic fertilizing, additionally using mineral fertilization.

For the forestation one of two years old material was grown in the distances of $1 \times 1 \mathrm{~m}$.

\subsection{The Areas with 10 Years Old Tree Stands}

Before the forestation, this area was fertilized with humus in the dose of $30 \mathrm{Mg} / \mathrm{ha}$, enriched with mineral fertilizers in the total dose of $\mathrm{N}-50 \mathrm{~kg} / \mathrm{ha}, \mathrm{K}-70 \mathrm{~kg} / \mathrm{ha}$, $\mathrm{P}_{2} \mathrm{O}_{5}-90 \mathrm{~kg} / \mathrm{ha}$, and then for one season the mixture of leguminous plants (the field bean Vicia faba var. minor) and cereals (rye - Secale cereale) were cultivated, and in the second year the plantation of the European yellow lupine (Lupinus luteus) with ploughing the green mass was cultivated.

The centre of the plot has the following geographic coordinates: $50^{\circ} 15^{\prime} 52.83^{\prime \prime} \mathrm{N}$ / 19²3'55.84"E.

\subsection{The Areas with 20 Years Old Tree Stands}

Before the forestation the surface was fertilized in the doses: $\mathrm{N}-50 \mathrm{~kg} / \mathrm{ha}$, $\mathrm{K}-60 \mathrm{~kg} / \mathrm{ha}$ and $\mathrm{P}_{2} \mathrm{O}_{5}-120 \mathrm{~kg} / \mathrm{ha}$, and then for two seasons the European yellow lupine (Lupinus luteus) was sown in the dose of $200 \mathrm{~kg} / \mathrm{ha}$, which was ploughed and converted into green fertilizer. In the second year the young trees were additionally supplemented with nitrogen in the dose of $40 \mathrm{~kg} \mathrm{~N} / \mathrm{ha}$.

The centre of the plot has the following geographic coordinates: $50^{\circ} 15^{\prime} 19.00^{\prime \prime} \mathrm{N}$ $/ 19^{\circ} 22^{\prime} 42.14^{\prime \prime} \mathrm{E}$.

\subsection{The Areas with 30 Years Old Tree Stands}

Before forestation, bentonite was introduced in the dose of $30 \mathrm{Mg} / \mathrm{ha}$ and peat in the dose of $200 \mathrm{Mg} / \mathrm{ha}$ as well as mineral fertilization in the following doses: 
$\mathrm{N}-60 \mathrm{~kg} / \mathrm{ha}, \mathrm{K}-60 \mathrm{~kg} / \mathrm{ha}$ and $\mathrm{P}_{2} \mathrm{O}_{5}-70 \mathrm{~kg} / \mathrm{ha}$ and for one season the European yellow lupine (Lupinus luteus) was cultivated and ploughed as green fertilizer.

In the second year of vegetation, the young trees were supplemented with nitrogen fertilization in the dose of $40 \mathrm{~kg} \mathrm{~N} / \mathrm{ha}$.

The centre of the plot has the following geographic coordinates: $50^{\circ} 15^{\prime} 12.25^{\prime \prime} \mathrm{N}$ / 19² $21^{\prime} 06.81^{\prime \prime} \mathrm{E}$.

\subsection{The Areas with 40 Year Old Tree Stands}

Before the forestation humus was provided in the dose of $200 \mathrm{Mg} / \mathrm{ha}$, mineral fertilization was in the following doses: $\mathrm{N}-30 \mathrm{~kg} / \mathrm{ha}, 40 \mathrm{~kg} / \mathrm{ha}$ and $\mathrm{P}_{2} \mathrm{O}_{5} 80 \mathrm{~kg} / \mathrm{ha}$, and then the European yellow lupine (Lupinus luteus) was sown in the dose of $150 \mathrm{~kg} / \mathrm{ha}$. During blooming the lupine was ploughed and converted into green fertilizer. In the second year the young trees were fertilized with nitrogen in the dose of $30 \mathrm{kgN} / \mathrm{ha}$.

The centre of the plot has the following geographic coordinates: $50^{\circ} 15^{\prime} 06.91^{\prime \prime} \mathrm{N}$ $/ 19^{\circ} 18^{\prime} 10.79^{\prime \prime} \mathrm{E}$.

\section{The Methods of the Field and Laboratory Studies}

On each of the marked plots a fragment of uniform pine tree stand was selected and then a square was determined of the side of about $10 \times 10 \mathrm{~m}$. In the corners and on the crossings of diagonals the samples were taken from the organic horizon $\left(\mathrm{O}_{\mathrm{If}}\right)$ from the area of $1 \mathrm{~m}^{2}$ and from the distinguishable organic-mineral horizon $\left(\mathrm{A}_{\mathrm{an}} \mathrm{C}_{\mathrm{an}}\right)$ of the thickness ranging from $4 \mathrm{~cm}$ to a maximum of $11 \mathrm{~cm}$, as well as the depth of about $40 \mathrm{~cm}$ representing the unchanged bedrock $\left(\mathrm{C}_{\mathrm{an}}\right)$.

In total, to the laboratory studies 60 samples were taken from organic and mineral horizons.

After drying in a temperature of about $40^{\circ} \mathrm{C}$ the samples were homogenised and sieved, and then the analyses was done. The obtained results were calculated into the content in the dry mass $\left(105^{\circ} \mathrm{C}\right)$. In the samples of intact structure their volume densities were measured. They served to the calculation of the mass of subsequent horizons and the content of carbon and nitrogen on one hectare.

In the laboratory studies the following values were determined:

- $\mathrm{pH}$ - potentiometric method in $\mathrm{H}_{2} \mathrm{O}$ and in $1 \mathrm{M} \mathrm{KCl}$ with the soil: dilution proportion equalling 1:5 in mineral samples and 1:10 in organic samples;

- electrolytic specific conductivity with the electrolytic-resistance sensor at a temperature of $25^{\circ} \mathrm{C}$ in the proportion soil: solution equalling 1:5;

- content total carbon (total carbon $\mathrm{C}_{\mathrm{t}}$ ) on the instrument ELTRA CS 50;0

- total nitrogen $\left(\mathrm{N}_{\mathrm{og}}\right)$ with the Kjeldahl method in the Büchi set. 


\section{The Results of the Studies}

The organic horizon in all the plots is not very changeable and strongly acid. This is caused by the shedding of pine needles and their decomposition. The $\mathrm{pH}$ values in the humus horizon are more changeable both within the studied plots, as well as between them and correspond to the acid reactions in younger tree stands and slightly acid older tree stands (Tab. 1). In the case of the oldest areas, slightly higher $\mathrm{pH}$ values in the organic-mineral horizon in 1970s were caused by the emission of dust from the nearby factory, which was (among others) confirmed by [6]. In relation to the recorded at that time values, the $\mathrm{pH}$ lowered as a result of the limitation of emission as well as the activity of the acidifying factor (rinsing acids from the organic horizon). In the horizon of the bedrock, the values of $\mathrm{pH}$ were very similar in all the studied plots and showed slight acid reaction.

Table 1. Mean values of $\mathrm{pH}$ in $1 \mathrm{M} \mathrm{KCl}$ with standard deviation in the experimental plots

\begin{tabular}{|c|c|c|c|c|c|c||}
\hline \multirow{2}{*}{ Age [years] } & \multicolumn{2}{|c|}{ Horizon $\mathrm{O}_{\mathrm{lf}}$} & \multicolumn{2}{c|}{ Horizon $\mathrm{A}_{\mathrm{an}} \mathrm{C}_{\mathrm{an}}$} & \multicolumn{2}{c||}{ Horizon $\mathrm{C}_{\mathrm{an}}$} \\
\cline { 2 - 7 } & $\mathrm{pH}$ in $\mathrm{KCl}$ & stand. dev. & $\mathrm{pH}$ in $\mathrm{KCl}$ & stand. dev. & $\mathrm{pH}$ in $\mathrm{KCl}$ & stand. dev. \\
\hline \hline 10 & 4.06 & 0.11 & 5.32 & 0.23 & 5.88 & 0.44 \\
\hline 20 & 4.14 & 0.11 & 5.14 & 0.17 & 5.68 & 0.15 \\
\hline 30 & 3.88 & 0.08 & 5.60 & 0.96 & 5.76 & 0.33 \\
\hline 40 & 4.26 & 0.11 & 6.26 & 0.37 & 5.94 & 0.47 \\
\hline
\end{tabular}

Electrolytic conductivity is characterized by the formation of a small content of salt easily soluble in water. It ranges from $285 \mu \mathrm{S} / \mathrm{cm}$ to $380 \mu \mathrm{S} / \mathrm{cm}$ in the organic layer. With the depth, the decrease of compounds influencing the conductivity takes place (Tab. 2).

Table 2. Mean electrolytic conductivity values in $\mu \mathrm{S} / \mathrm{cm}$ in the subsequent horizons of the experimental plots

\begin{tabular}{|c|c|c|}
\hline Horizon & Mean & Standard deviation \\
\hline \hline $\mathrm{O}_{\mathrm{If}}$ & 321 & 30 \\
\hline $\mathrm{A}_{\mathrm{an}}$ & 21 & 5 \\
\hline $\mathrm{C}_{\mathrm{an}}$ & 14 & 7 \\
\hline
\end{tabular}

In these formations the content of total carbon can be treated the same as the content of organic carbon, because they are soilless formations of simple mineralogical composition (quartz), where the only source of carbon is organic matter.

The amount of the accumulated carbon is strictly connected with the time of the growth of the tree stands (Tab. 3). 
Table 3. Mean content of total carbon in the organic horizon $\mathrm{O}_{\mathrm{lf}}$ and initial organic-mineral horizon $\mathrm{A}_{\mathrm{an}} \mathrm{C}_{\mathrm{an}}$ in the experimental plots

\begin{tabular}{|c|c|c|c|c|c|c|c|}
\hline \multirow{2}{*}{$\begin{array}{c}\text { Age } \\
\text { [years] }\end{array}$} & \multicolumn{3}{|c|}{$\mathrm{O}_{\text {If }}$} & \multicolumn{3}{|c|}{$\mathrm{A}_{\mathrm{an}} \mathrm{C}_{\mathrm{an}}$} & \multirow{2}{*}{$\begin{array}{c}\text { Total C } \\
{[\mathrm{Mg} / \mathrm{ha}]}\end{array}$} \\
\hline & {$[\mathrm{mg} / \mathrm{g}]$} & $\begin{array}{l}\mathrm{O}_{\mathrm{If}} \text { mass } \\
{[\mathrm{Mg} / \mathrm{ha}]}\end{array}$ & $\begin{array}{c}\text { C amount } \\
{[\mathrm{Mg} / \mathrm{ha}]}\end{array}$ & {$[\mathrm{mg} / \mathrm{g}]$} & $\begin{array}{c}\mathrm{A}_{\mathrm{an}} \mathrm{C}_{\mathrm{an}} \text { mass } \\
{[\mathrm{Mg} / \mathrm{ha}]}\end{array}$ & $\begin{array}{l}\text { C amount } \\
{[\mathrm{Mg} / \mathrm{ha}]}\end{array}$ & \\
\hline 10 & $\frac{250-270}{255}$ & $\frac{26-38}{33}$ & 8.41 & $\frac{1.07-1.65}{1.30}$ & $\frac{660-810}{753}$ & 0.98 & 9.39 \\
\hline 20 & $\frac{320-340}{332}$ & $\frac{40-42}{41}$ & 13.61 & $\frac{1.08-2.54}{1.77}$ & $\frac{980-1260}{1120}$ & 1.98 & 15.59 \\
\hline 30 & $\frac{370-395}{378}$ & $\frac{48-56}{52}$ & 19.66 & $\frac{3.32-3.46}{3.38}$ & $\frac{1280-1660}{1475}$ & 4.98 & 24.64 \\
\hline 40 & $\frac{390-410}{402}$ & $\frac{52-64}{55}$ & 22.11 & $\frac{5.20-5.61}{5.38}$ & $\frac{1260-1680}{1490}$ & 8.02 & 30.13 \\
\hline
\end{tabular}

Notice:

$\underline{36-4} \quad \underline{\min -\max }$

The highest content of carbon is in the organic horizon, while in the period of growth the mean annual amount of the accumulated carbon decreases in this layer, which can be the result of both diminishing the number of trees as well as the translocation of organic compounds into a deeper horizon. The confirmation of the second process is the increase of carbon in the organic-mineral horizon. In total, after forty years of growth, tree stands were found in two levels of above $30 \mathrm{Mg}$ of carbon, which is the value from 2 to 4 times smaller than the amount of organic carbon in natural forest soils in Poland [1]. Much smaller is the content in the relation to fully formed soils and the annual increase proves the constant development of these initial soils and the advantage of accumulation over decomposition.

The amount of the accumulated total nitrogen shows constant increase, however, significantly smaller in the relation to the increase of carbon. In the organic horizon the increase within the first decade was about $14 \mathrm{~kg} / \mathrm{ha}$, while in the organic-mineral horizon it was about $8 \mathrm{~kg} / \mathrm{ha}$, and in both horizons in total - about $22 \mathrm{~kg} / \mathrm{ha} / \mathrm{a}$. In the following decades the mean annual increase of nitrogen in levels $\mathrm{O}$ and $\mathrm{A}$ ranged from $19 \mathrm{~kg} / \mathrm{ha}$ to $25 \mathrm{~kg} / \mathrm{ha}$. The decrease of the rate of increase in the $w$ organic horizon, at higher accumulation in the organic-mineral horizon. After forty years of growth the sum of the content of nitrogen in both horizons was above $860 \mathrm{~kg} / \mathrm{ha}$ The results of the contents of total nitrogen was put together in table 4 . 
Table 4. Mean contents of total nitrogen in the organic horizon $\mathrm{O}_{\mathrm{lf}}$ and the initial organic-mineral horizon $\mathrm{A}_{\mathrm{an}} \mathrm{C}_{\mathrm{an}}$ in the experimental plots

\begin{tabular}{|c|c|c|c|c|c|c|c|}
\hline \multirow{2}{*}{$\begin{array}{c}\text { Age } \\
\text { [years] }\end{array}$} & \multicolumn{3}{|c|}{$\mathrm{O}_{\mathrm{lf}}$} & \multicolumn{3}{|c|}{$\mathrm{A}_{\mathrm{an}} \mathrm{C}_{\mathrm{an}}$} & \multirow{2}{*}{$\begin{array}{l}\text { Total N } \\
{[\mathrm{kg} / \mathrm{ha}]}\end{array}$} \\
\hline & {$[\mathrm{mg} / \mathrm{g}]$} & $\begin{array}{l}\mathrm{O}_{\mathrm{lf}} \text { mass } \\
{[\mathrm{Mg} / \mathrm{ha}]}\end{array}$ & $\begin{array}{c}\mathrm{N} \text { amount } \\
{[\mathrm{kg} / \mathrm{ha}]}\end{array}$ & {$[\mathrm{mg} / \mathrm{g}]$} & $\begin{array}{c}\mathrm{A}_{\mathrm{an}} \mathrm{C}_{\mathrm{an}} \text { mass } \\
{[\mathrm{Mg} / \mathrm{ha}]}\end{array}$ & $\begin{array}{c}\mathrm{N} \text { amount } \\
{[\mathrm{kg} / \mathrm{ha}]}\end{array}$ & \\
\hline 10 & $\frac{3.8-4.6}{4.2}$ & $\frac{26-38}{33}$ & 138 & $\frac{0.08-0.15}{0.11}$ & $\frac{660-810}{753}$ & 83 & 221 \\
\hline 20 & $\frac{4.6-5.7}{5.2}$ & $\frac{40-42}{41}$ & 213 & $\frac{0.13-0.21}{0.18}$ & $\frac{980-1260}{1120}$ & 201 & 414 \\
\hline 30 & $\frac{5.0-6.0}{5.6}$ & $\frac{48-56}{52}$ & 291 & $\frac{0.19-0.31}{0.26}$ & $\frac{1280-1660}{1475}$ & 384 & 675 \\
\hline 40 & $\frac{5.8-6.2}{5.9}$ & $\frac{52-64}{55}$ & 325 & $\frac{0.31-0.46}{0.36}$ & $\frac{1260-1680}{1490}$ & 536 & 861 \\
\hline
\end{tabular}

\section{Interpretation of The Results}

The research was carried out on the surfaces built from the formations of extremely unfavourable properties resulting from the granulometric composition of the soilless formations before forestation. The applied organic and mineral fertilization raised their fertility and formed the condition to introduce forest-forming species. They should emphasize that the carried out fertility increase influences the contents not only in the first period of growth, expressed with higher accumulation of carbon on the level of about $1 \mathrm{Mg} / \mathrm{ha} / \mathrm{a}$. In the following decades the rate of the accumulation was smaller, both in terms of carbon, as well as nitrogen and this was the result of the formation of new organic compounds "in situ". In the case of the studies on these formations, the increase of nitrogen according to the proposed by Gołda classification, it is on a low level ranging from about $18-26 \mathrm{~kg} / \mathrm{ha} / \mathrm{a}$ [3]. This proves a slow increase, resulting from very low fertility of these formations, which will significantly prolong the time necessary for the accumulation of carbon or nitrogen in the amount close to the recorded in natural soils formed from a similar bedrock.

\section{Conclusions}

The reclamation to make a forest, carried out on the formations of very low fertility of former excavations of stowing sand quarries, required the application of proper fertilizing techniques. The introduction of the organic matter and the 
carried out NPK fertilization allowed to increase the initial richness of these formations and introduction of forest-forming species. The growth of vegetation initiated soil-making processes by providing the organic matter, the accumulation of which and chemical changes contributed to the formation of two distinct horizons. The carried out studies document the development of newly formed initial soils, however, the dynamics of the increase of carbon and nitrogen is low, which will significantly prolong the time necessary to achieve the climax stage in these formations. It can be estimated that the time necessary to accumulate these two elements in the amounts occurring in the pine wood habitats in Poland will exceed 200 years.

\section{References}

[1] Brożek S., Zwydak M.: Atlas gleb leśnych Polski. Centrum Informacyjne Lasów Państwowych, Warszawa 2003.

[2] Chodak M., Niklińska M.: The effect of different tree species on the chemical and microbial properties of reclaimed mine soils. Bio Fertil Soils, 46, 2010, pp. 555-566.

[3] Gołda T.: The increase of total nitrogen content in soilless formations as a criterion of the efficiency of reclamation measures. [in:] Environmental Engineering III, Taylor \& Francis Group, London 2010, pp. 371-374.

[4] Katzur J., Böcker L., Stahr F.: Humus-und Bodenentwicklung in Kippen Forstokosystemen. AFZ, Der Wald, 25, 1999, pp. 1331-1341.

[5] Kowalik S., Wójcik J.: Symptomy rozwoju glebotwórczego pod młodymi zalesieniami rekultywacyjnymi na spagu wyrobiska Kopalni Piasku "Szczakowa". Inżynieria Środowiska, t. 10, z. 2, 2005, pp. 185-194.

[6] Pietrzykowski M. (red.): Analiza i optymalizacja metod klasyfikacji siedlisk i kryteriów oceny rekultywacji leśnej na wybranych terenach pogórniczych w Polsce. Wydawnictwo Uniwersytetu Rolniczego w Krakowie, Kraków 2010.

[7] Sourkova M., Frouz J., Szntuckowa H.: Accumulation of carbon, nitrogen i phosphorus during soil formation on alder spoil heaps after Brown-coal mining, near Sokolov (Czech Republic). Geoderma, 124, 2005, pp. 203-214.

[8] Węgorek T.: Zmiany niektórych właściwości materiału ziemnego i rozwój fitocenoz na zwałowisku zewnętrxym kopalni siarki w wyniku leśnej rekultywacji docelowej. Rozprawy Naukowe Akademii Rolniczej w Lublinie, z. 275, 2003. 